\title{
Effect of the Growth Regulator Paclobutrazol on Growth of the Bacterial Pathogen Xylella fastidiosa
}

\author{
Darren A. DeStefano, Arv P. Grybauskas, James L. Sherald, Bahram Momen, Qi Huang, and \\ Joe H. Sullivan
}

\begin{abstract}
Xylella fastidiosa is a fastidious, xylem-limited, insect-transmitted, bacterial plant pathogen with a wide host range that causes bacterial leaf scorch (BLS) in shade trees. BLS is a chronic disorder characterized by late season leaf scorch and dieback and is common in urban and suburban areas of the mid-Atlantic and southeast United States. BLS has been recognized since the 1980s and attempted treatments have included antibiotics and plant growth regulators. Application of paclobutrazol (PBZ), a diastereomeric triazole with both fungistatic and growth regulation properties, has been observed to alleviate symptoms of BLS, but it has not been established whether PBZ has a direct effect on the organism. In this study, we investigated the effect of PBZ on in vitro growth of two $X$. fastidiosa isolates. Our results showed no significant effect of PBZ on colony growth of X. fastidiosa at the manufacturers recommended rate of $20 \mu \mathrm{g} / \mathrm{mL}^{-1}$. However, significant reductions in bacterial growth were observed at a rate of $200 \mu \mathrm{g} / \mathrm{mL}^{-1}$, indicating that high levels of PBZ may have a direct effect on the growth of $X$. fastidiosa. This direct effect and growth regulator effects of PBZs suggest that PBZ may provide a promising treatment for BLS in shade trees.
\end{abstract}

Key Words. Bacterial leaf scorch; oxytetracycline; paclobutrazol; Xylella fastidiosa.

Xylella fastidiosa (Wells et al. 1987) is a xylem-limited, insect-transmitted, fastidious plant pathogenic bacterium with a wide host range. It is currently recognized as indigenous to the Americas and causes disease in grape, citrus, shade trees, and other hosts. Pierce's disease of grape, caused by the bacterium, was first described by Newton B. Pierce in 1892 (Pierce 1892) as an irregular marginal necrosis that resulted in the slow systematic death of the vine. Transmission of the bacterium by arthropods of the Homoptera was confirmed by Houston et al. in 1947. In the 1950s, marginal leaf scorching symptoms similar to Pierce's disease were observed on American elms (Ulmus americana) in Washington, DC, U.S. (Wester and Jylkka, 1959) leading to a hypothesized relationship between the syndromes. The isolation of a xylem-limited bacterium confirmed to be the casual agent of Pierce's disease (Davis et al. 1978) subsequently enabled scientists to implicate this bacterium as the cause of a variety of syndromes, including elm leaf scorch (Hearon et al. 1980), phony disease of peach (Hopkins and Mollenhauer 1973), and almond leaf scorch (Mircetich et al. 1976). Analysis of 25 isolates of the pathogen from 10 distinct hosts in 1987 allowed Wells et al. to describe and name the organism $X$. fastidiosa as a new genus of plant pathogenic bacteria represented by a single species. In 2000, X. fastidiosa became the first plant pathogen to have its entire genome sequenced (Simpson et al. 2000).
Xylella fastidiosa infection in shade trees is commonly referred to as bacterial leaf scorch (BLS) and the causal role of the bacterium was first demonstrated by Sherald et al. (1983) in sycamore (Platanus occidentalis). Xylella fastidiosa has a wide host range affecting over 100 host species in at least 30 families of monocotyledonous and dicotyledonous plants (Hopkins and Alderz 1988), including such important landscape trees as oaks (Quercus), elms (Ulmus), sycamores (Platanus), and mulberries (Morus) in urban or suburban areas of the mid-Atlantic and southeastern United States (Sherald 2001). Xylella fastidiosa has been confirmed to infect numerous tree hosts (Table 1) throughout eastern North America and California, U.S. Most hosts are asymptomatic and may serve as reservoirs of the pathogen from which vectors transmit the disease to susceptible hosts. Xylella fastidiosa is transmitted by xylem-feeding insects of the Cicadellinae (sharpshooters/leafhoppers) and Cercopidae (spittlebugs), which are active throughout the growing season and remain infectious indefinitely after bacterial acquisition.

Bacterial leaf scorch is a chronic late season leaf scorch that compromises the growth and aesthetic qualities of shade trees, although it is rarely lethal. Symptoms of the disease include an irregular marginal leaf scorch, early defoliation, delayed budbreak, loss of vigor, stunting, and dieback. Scorch symptoms result from the disruption of water transport attributable to bacterial aggregation in xylem vessel el- 
Table 1. Shade tree hosts of Xylella fastidiosa.

\begin{tabular}{|c|c|c|c|}
\hline Scientific name & Common name & Scientific name & Common name \\
\hline Acer negundo & Boxelder & Q. incana & Bluejack oak \\
\hline A. rubrum & Red maple & Q. laevis & Turkey oak \\
\hline A. saccharum & Sugar maple & Q. laurifolia & Laurel oak \\
\hline Cornus florida & Flowering dogwood & Q. macrocarpa & Burr oak \\
\hline Celtis occidentalis & Hackberry & Q. nigra & Water oak \\
\hline Liquidambar styraciflua & Sweetgum & Q. palustris & Pin oak \\
\hline Morus alba & White mulberry & Q. phellos & Willow oak \\
\hline Platanus occidentalis & American sycamore & $Q$. prinus & Chestnut oak \\
\hline$P . \times$ acerifolia & London plane & Q. rubra & Northern red oak \\
\hline Quercus alba & White oak & Q. shumardii & Shumard oak \\
\hline Q. bicolor & Swamp white oak & Q. stellata & Post oak \\
\hline Q. coccinea & Scarlet oak & Q. velutina & Black oak \\
\hline$Q$ falcate & Southern red oak & Q. virginiana & Live oak \\
\hline Q. imbricaria & Shingle oak & Ulmus americana & American elm \\
\hline
\end{tabular}

ements and are usually apparent by late summer with severity varying annually as a function of moisture availability (McElrone et al. 2001). Affected trees will appear less vigorous with a noticeable reduction in growth over the long term. The bacteria spread systemically through the xylem of the tree; symptoms typically begin on a single branch and progress to adjacent branches and ultimately the entire canopy over several years. The disease is commonly reported in urban and suburban areas and is less commonly seen in natural areas.

Treatment of BLS was first attempted using the antibiotic oxytetracycline with some success. However, treatment did not prove curative and symptom remission was highly variable (Kostka et al. 1985). Paclobutrazol (PBZ) is a diastereomeric triazole (Sugavanam 1984) that possesses properties of gibberellin (Radenmacher et al. 1987) and sterol biosynthesis inhibition (Burden et al. 1987). The compound reduces shoot growth, confers drought tolerance to plants (Frakulli and Voyiatzis 1999), and inhibits mycelial growth of a wide range of fungi (Jacobs and Berg, 2000). Paclobutrazol is considered a multiprotector as a result of its ability to ameliorate biotic and abiotic stresses in plants (Fletcher and Hofstra 1986). Application of PBZ to oak trees exhibiting BLS has been observed to alleviate symptoms (The Bartlett Tree Research Laboratories, pers. comm.); however, this remains to be validated through experimental studies. Currently, there is no evidence that PBZ directly inhibits growth or survival of $X$. fastidiosa. The purpose of this study was to determine whether PBZ inhibits growth of $X$. fastidiosa in vitro.

\section{MATERIALS AND METHODS}

\section{Bacterial Isolates and Culture}

Studies were conducted using X. fastidiosa isolates from elm (Ulmus americana) and grape (Vitis vinifera) grown on semisolid periwinkle wilt (PW) medium (Davis et al. 1981). Iso- lates had been held in storage at $-70^{\circ} \mathrm{C}\left(-158^{\circ} \mathrm{F}\right)$. All strains were transferred to and maintained on buffered charcoal yeast extract (BCYE) semisolid medium (Feeley et al. 1979) and in $\mathrm{PW}$ broth at $28^{\circ} \mathrm{C}\left(82.4^{\circ} \mathrm{F}\right)$ and subcultured on a regular basis.

\section{Standard Curve}

A Spectronic Genesis 5 spectrophotometer (Spectronic Instruments, Inc., Rochester, NY) was used to measure the absorption at $600 \mathrm{~nm}$ of $X$. fastidiosa cells in PW broth cultures. Broth cultures with a range of cell densities were measured by spectrophotometer and subsequently diluted logarithmically to allow direct determination of bacterial colonyforming units, the number of separate bacterial colonies observed (CFUs) from the absorbance measures. Dilution series were executed by plating a $100 \mu \mathrm{L}$ aliquot of each sample on BCYE followed by a 10-fold dilution; this was repeated until the $1 \times 10^{10}$ dilution was achieved. Plates were incubated at $28^{\circ} \mathrm{C}\left(82.4^{\circ} \mathrm{F}\right)$ and the number of $\mathrm{CFUs}$ counted. Absorbance values were plotted as a function of the number of colonies and evaluated by regression analysis using statistical analysis software (SAS) to determine the best fit model for the calculation of CFUs from absorbance readings (Figure 1).

\section{Inoculum}

Elm and grape isolates of $X$. fastidiosa were grown for 10 days on BCYE semisolid medium. Cells were scraped and suspended in PW broth. Cultures were incubated for 5 days at $28^{\circ} \mathrm{C}\left(82.4^{\circ} \mathrm{F}\right)$ and standardized to $\approx 1 \times 10^{4}$ CFUs using a spectrophotometer.

\section{Treatments}

Oxytetracycline, $50 \mu \mathrm{g} / \mathrm{mL}^{-1}$, was used as the treated control. A $50 \mu \mathrm{g} / \mathrm{mL}^{-1}$ oxytetracycline solution was prepared by dissolving $5 \mathrm{mg}$ of oxytetracycline in $10 \mathrm{~mL}(0.3 \mathrm{fl} \mathrm{oz}) \mathrm{PW}$ 


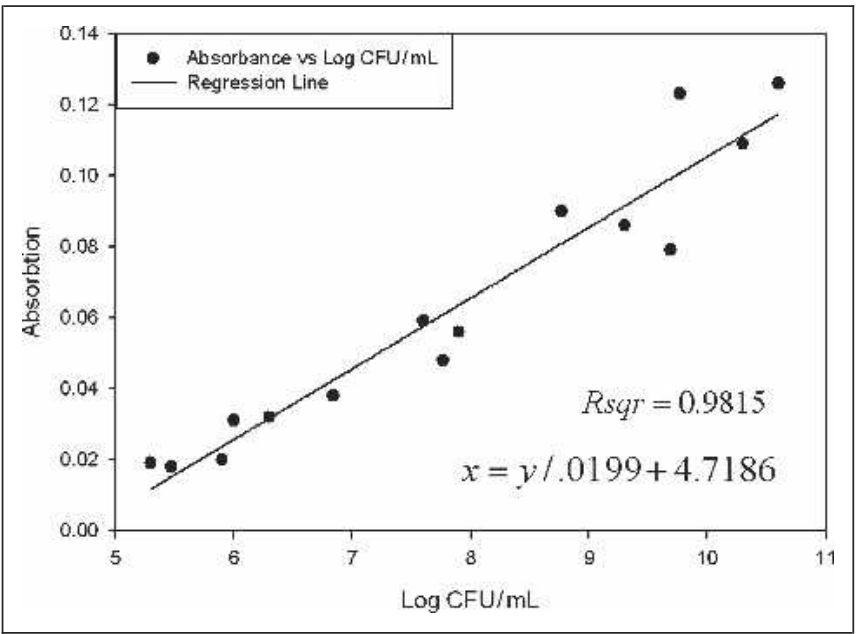

Figure 1. The relationship between absorbance of a periwinkle wilt broth sample measured by a spectrophotometer and amount of Xylella fastidiosa colony-forming units (CFUs) within the sample as determined by dilution plating.

broth. The broth was filter sterilized through a $0.22 \mu \mathrm{M}$ Millipore membrane and added to $90 \mathrm{~mL}(2.7 \mathrm{fl} \mathrm{oz})$ of the $\mathrm{PW}$ broth.

Three $10 \mathrm{~mL}(0.3 \mathrm{fl} \mathrm{oz})$ stock solutions of technical-grade PBZ (Syngenta Crop Protection Inc., Greensboro, NC) were prepared in $95 \%$ ethanol at the concentration of 2000, 200, and $20 \mu \mathrm{g} / \mathrm{mL}^{-1}$ and stored at room temperature. Aliquots of $100 \mu \mathrm{L}$ from each PBZ stock were applied to $100 \mathrm{~mL}$ (3 fl oz) PW broth to make 200, 20, and $2 \mu \mathrm{g} / \mathrm{mL}^{-1}$ PBZ solutions.

\section{Growth Study}

Growth studies were conducted using $1.5 \mathrm{~mL}(0.05 \mathrm{fl} \mathrm{oz})$ sterile microcentrifuge tubes. Nine hundred microliter aliquots of each solution (control PW broth, $50 \mu \mathrm{g} / \mathrm{mL}^{-1}$ oxytetracycline, $200 \mu \mathrm{g} / \mathrm{mL}^{-1} \mathrm{PBZ}, 20 \mu \mathrm{g} / \mathrm{mL}^{-1} \mathrm{PBZ}, 2 \mu \mathrm{g} /$ $\mathrm{mL}^{-1}$ PBZ) were added to 40 tubes each. Subsequently, all treatments received $100 \mu \mathrm{L}$ of $X$. fastidiosa inoculum and were incubated for 10 days at $28^{\circ} \mathrm{C}\left(82.4^{\circ} \mathrm{F}\right)$. Uninoculated standards of each treatment served as references.

After incubation, three randomly selected microcentrifuge tubes from each respective treatment were removed each day for 10 days and absorbance determined by spectrophotometry. References of each respective media from the same media batch were used in duplicate to ensure consistency and accuracy. Additionally, a logarithmic series of dilutions in sterile water was prepared for a randomly selected sample from each treatment everyday to ensure purity of the cultures and accuracy of the spectrophotometer. Dilutions were plated each day for the first 5 days on BCYE and subsequently incubated for 10 days after which time bacterial colonies were counted.

\section{RESULTS}

\section{Standard Curve}

A simple linear regression equation $[y=0.0199 x-0.0939]$, where $y$ is the number of CFUs and $x$ is the absorption, was produced. The absorption depended on the CFUs in the broth culture. Therefore, inverse regression was used to calculate CFUs from absorbance measurements. Inverse regression was done by regressing absorbance values on CFUs, resulting in the equation $[x=50.25 y+4.7186]$.

\section{Evaluation of the Effect of Paclobutrazol on $X$. fastidiosa by Spectrophotometery}

Treatments of oxytetracycline at $50 \mu \mathrm{g} / \mathrm{mL}^{-1}$ and PBZ at 200 $\mu \mathrm{g} / \mathrm{mL}^{-1}$ significantly reduced the growth of both the elm and grape isolates of $X$. fastidiosa as compared with the PW medium control or the PBZ treatments at $2 \mu \mathrm{g} / \mathrm{mL}^{-1}$ and 20 $\mu \mathrm{g} / \mathrm{mL}^{-1}$ (Figure 2; Table 2). No significant growth difference was observed between the two $X$. fastidiosa isolates under any of the treatments (Figure 2; Table 2).

\section{Evaluation of the Effect of Paclobutrazol on $X$. fastidiosa by Dilution Plating}

Both oxytetracycline and PBZ at $200 \mu \mathrm{g} / \mathrm{mL}^{-1}$ reduced the number of CFUs of $X$. fastidiosa isolates from elm $(P<0.01)$ and grape $(P<0.01)$ when compared with the control or low levels of PBZ (Table 3). However, in grape and elm tissue, PBZ was not as effective in delaying or reducing bacterial growth as oxytetracycline (Figure 3).

\section{DISCUSSION}

Paclobutrazol has been observed to reduce BLS symptom development at a rate of $20 \mu \mathrm{g} / \mathrm{mL}^{-1}$ on oak trees (The Barlett Tree Research Laboratories, pers. comm.); however, the consistency and mode of action of this treatment has not been determined. Symptom remission may result from an indirect effect of physiological changes within the tree induced by PBZ. Such changes have been suggested to include alteration in the size and/or conformation of the xylem vessel elements or reduced stomatal conductance rather than an effect on the bacteria itself. These physiological alterations could ease or reduce the resistance to water movement in the xylem or enhance water use efficiency through improved stomatal control (Frakulli and Voyiatzis 1999), which could result in less acute drought stress. Indeed, if the full suite of physiological changes attributed to PBZ (including increased root/shoot ratio, increased spongy leaf mesophyl, and altered xylem vessels) was realized, treated trees could have a distinct advantage over untreated trees, especially during drought when $X$. fastidiosa symptoms are most evident.

However, in addition to these indirect responses, the results of this study show that PBZ effectively suppresses the growth of $X$. fastidiosa in vitro when applied at $200 \mu \mathrm{g} / \mathrm{mL}^{-1}(10 \times$ 


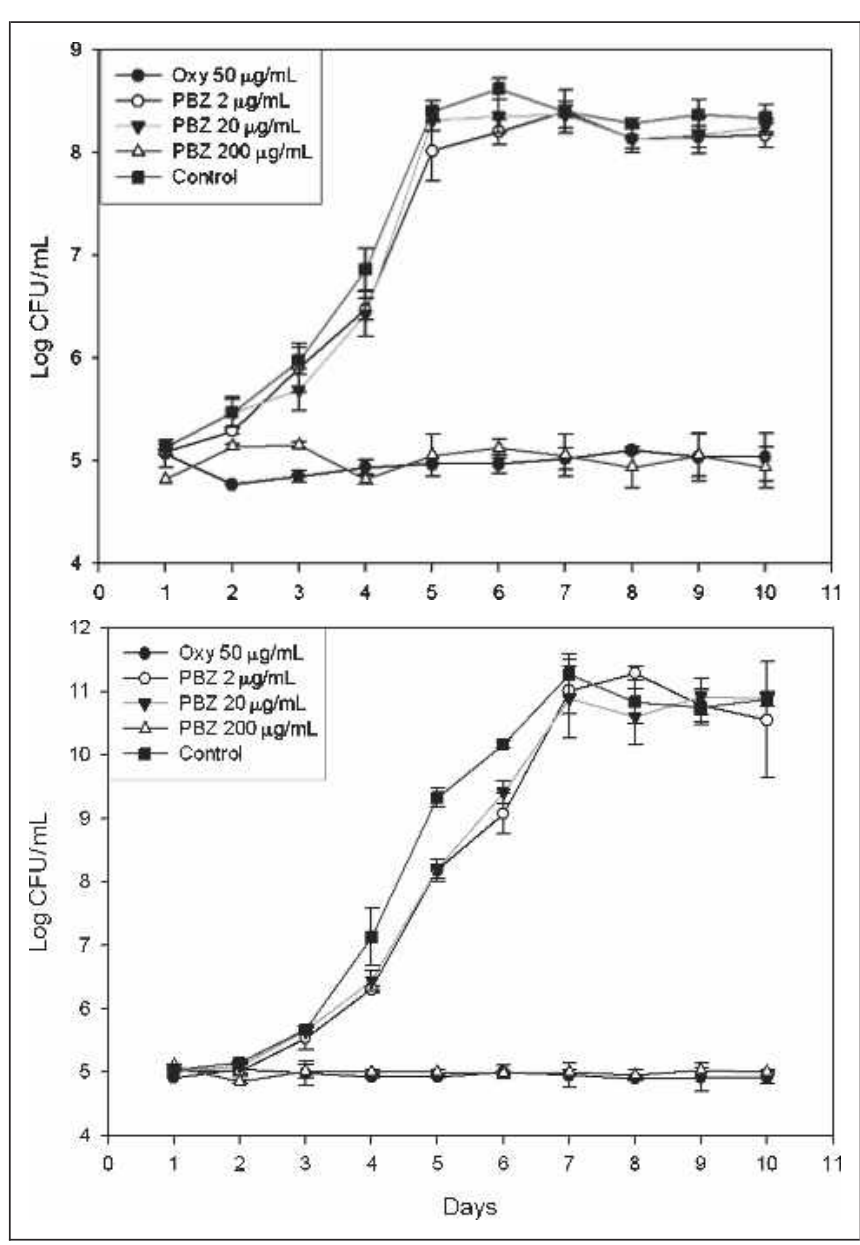

Figure 2. Growth curve of Xylella fastidiosa isolate elm (top) and grape (bottom) in periwinkle wilt (PW) broth supplemented with chemical treatments of either oxytetracycline (antibiotic) or paclobutrazol (PBZ) measured over 10 days with a spectrophotometer. Absorbance readings were converted to colony-forming units (CFUs) using the regression equation (Figure 1) determined for this study. Means and associated standard errors are plotted.

the labeled rate). Therefore, in addition to a hypothesized indirect effect of PBZ through modification of plant water use efficiency, PBZ when applied at high rates may also restrict growth and survival of $X$. fastidiosa in planta. Although the mechanisms of this suppression are not yet known, a consideration of the chemical nature of PBZ leads to some hypotheses that may be tested in further studies.

The diastereomeric nature of PBZ may explain its dual function as both a growth regulator and a fungicide. The enantiomeric pair found in the commercially available PBZ is the 2RS, 3RS diastereomer, which exists as a racemic mixture including the $2 \mathrm{R}, 3 \mathrm{R}$ enantiomer, which has been found to
Table 2. Growth of Xylella fastidiosa isolates from elm and grape grown in periwinkle wilt broth supplemented with either oxytetracycline (antibiotic) or paclobutrazol (PBZ). ${ }^{2}$

\begin{tabular}{llc}
\hline & \multicolumn{2}{c}{ Mean $\log \mathrm{CFU} / \mathrm{mL}^{-1}$} \\
\cline { 2 - 3 } Treatment and dose & Elm & Grape \\
\hline Oxytetracycline $50 \mu \mathrm{g} / \mathrm{mL}^{-1}$ & $4.97 \mathrm{a}$ & $4.95 \mathrm{a}$ \\
PBZ $200 \mu \mathrm{g} / \mathrm{mL}^{-1}$ & $5.00 \mathrm{a}$ & $4.99 \mathrm{a}$ \\
PBZ $20 \mu \mathrm{g} / \mathrm{mL}^{-1}$ & $7.23 \mathrm{~b}$ & $8.31 \mathrm{~b}$ \\
PBZ $2 \mu \mathrm{g} / \mathrm{mL}^{-1}$ & $7.18 \mathrm{~b}$ & $8.27 \mathrm{~b}$ \\
Periwinkle wilt media & $7.38 \mathrm{~b}$ & $8.61 \mathrm{~b}$ \\
\hline
\end{tabular}

${ }^{\mathrm{z}}$ Growth was measured with a spectrophotometer and converted to colonyforming units (CFUs) using a regression equation (Figure 1).

Values are means of three replicates after 10 days of incubation.

Means in each column with identical letters are not significantly different at the 0.05 level by Tukey test SED $=0.028$ (elm), 0.52 (grape).

disrupt sterol biosynthesis (Sugavanam 1984; Burden et al. 1987). Analysis of the proposed biosynthetic pathways inferred from genomic data of $X$. fastidiosa (www.genome. ad.jp) shows a complete pathway for sterol biosynthesis, including lanosterol, the intermediary identified as disrupted by PBZ (Radenmacher 2000). The most simplistic explanation for the observed results of our study would be to implicate PBZ in the disruption of this pathway in line with previous studies of alternate pathosystems (Radenmacher 2000).

Alternatively, bacterial growth inhibition may be explained by the effects of high concentrations of PBZ sequestering an essential element such as iron required by $X$. fastidiosa. PBZ is a reactive molecule with electron pairs situated at the periphery facilitating the establishment of complexes with other elements, especially those that bond readily such as iron.

When considering the dual nature of PBZ and the possible synergistic effects of its enantiomers on X. fastidiosa-infected

Table 3. Growth of Xylella fastidiosa isolates elm and grape growth in periwinkle wilt broth supplemented with either oxytetracycline (antibiotic) or paclobutrazol (PBZ). ${ }^{z}$

\begin{tabular}{lll}
\hline & \multicolumn{2}{c}{ Mean $\log \mathrm{CFU} / \mathrm{mL}^{-1}$} \\
\cline { 2 - 3 } Treatment and dose & Elm & Grape \\
\hline Oxytetracycline $50 \mu \mathrm{g} / \mathrm{mL}^{-1}$ & $0.15 \mathrm{a}$ & $2.19 \mathrm{a}$ \\
PBZ $200 \mu \mathrm{g} / \mathrm{mL}^{-1}$ & $2.66 \mathrm{~b}$ & $3.64 \mathrm{~b}$ \\
PBZ $20 \mu \mathrm{g} / \mathrm{mL}^{-1}$ & $7.35 \mathrm{c}$ & $7.48 \mathrm{c}$ \\
PBZ $2 \mu \mathrm{g} / \mathrm{mL}^{-1}$ & $7.33 \mathrm{c}$ & $7.67 \mathrm{c}$ \\
Periwinkle wilt media & $7.61 \mathrm{c}$ & $7.98 \mathrm{c}$ \\
\hline
\end{tabular}

${ }^{\mathrm{z}}$ Growth was determined by dilution plating.

Values are means of three replicates after 10 days of incubation.

Means in each column with identical letters are not significantly different at the 0.05 level by the Tukey test SED $=0.040$ (elm), 0.037 (grape).

$\mathrm{CFU}=$ colony-forming unit. 


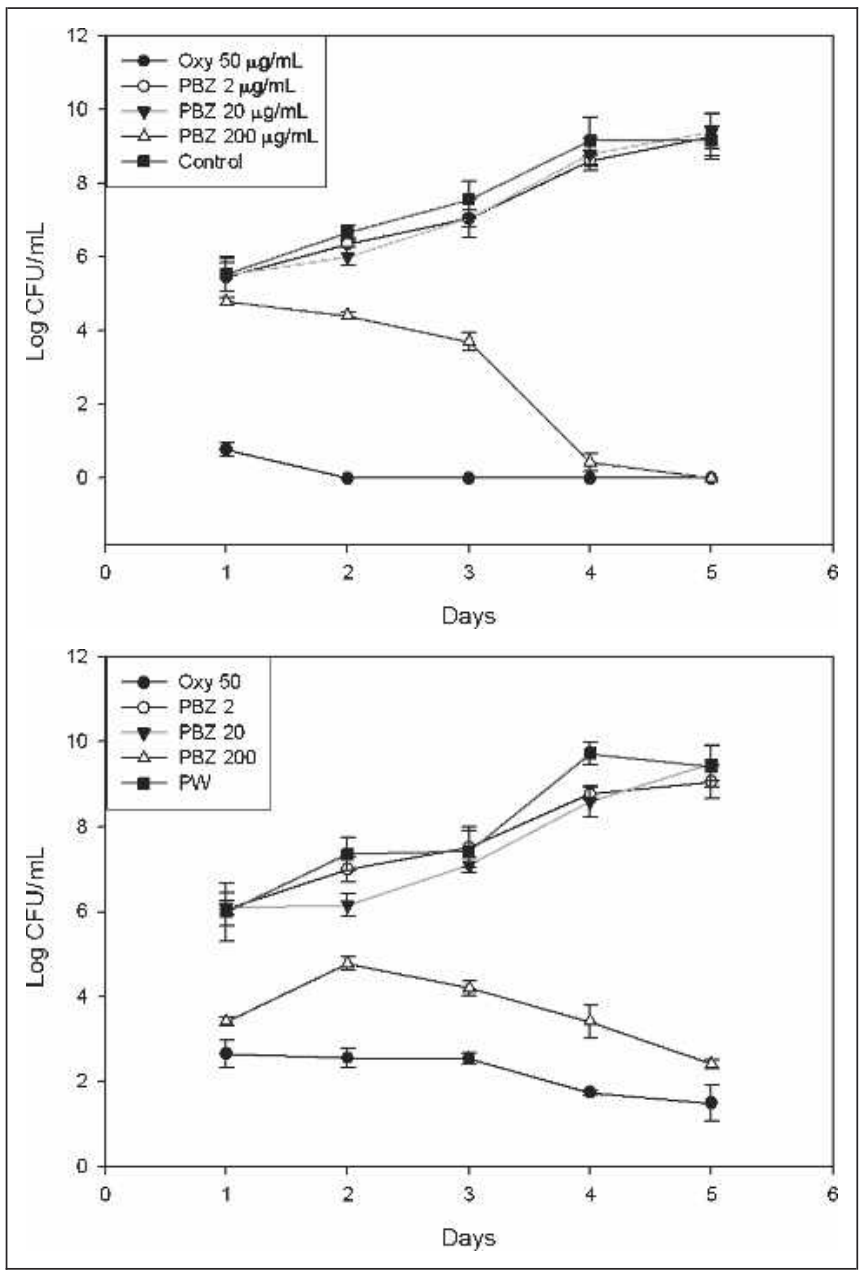

Figure 3. Growth curve of Xylella fastidiosa isolate elm (left) and grape (right) in periwinkle wilt (PW) broth supplemented with chemical treatments of oxytetracycline (antibiotic) and paclobutrazol (PBZ) measured over 5 days. Colony-forming units (CFUs) were determined by dilution plating. Means and associated standard errors are plotted.

hosts, it may not be desirable to separate the enantiomers of the diastereomer for treatment of X. fastidiosa. It is possible that a concentration of the racemic mixture could be devised that restricts bacterial growth as well as provide beneficial physiological changes to the tree. This would prove to be the ideal circumstance for use of the chemical. However, devising the most effective ratio and concentration of enantiomers could be complicated by a possible species-specific treatment response to PBZ and efficacy of the treatment may be dependent on the distribution, titer, and strain of $X$. fastidiosa being treated.

This study suggests that PBZ has a direct effect on growth of $X$. fastidiosa and that treatments with high levels of PBZ could provide a potential treatment. However, field experi- ments are needed to evaluate the effect of higher rates of PBZ on mature trees as well as their ability to control $X$. fastidiosa. Repeated treatments as well as methods and timing of delivery should also be investigated.

Acknowledgments. We thank the University of Maryland, Department of Plant Science and Landscape Architecture for partial support of this project through a Research Assistantship to the senior author. This work was completed in partial fulfillment of a Master of Science degree.

\section{LITERATURE CITED}

Burden, R.S., G.A. Carter, T. Clark, D.T. Cooke, S.J. Croker, A.H.B. Deas, P. Hedden, C.S. James, and J.R. Lenton. 1987. Comparative activity of the enantiomers of triadimenol and paclobutrazol as inhibitors of fungal growth and plant sterol and gibberellin biosynthesis. Pesticide Science 21:253-267.

Davis, M.J., W.J. French, and N.W. Schaad. 1981. Axenic culture of the bacteria associated with phony disease of peach and plum leaf scald. Current Microbiology 6:309-314.

Davis, M.J., A.H. Purcell, and S.V. Thomson. 1978. Pierce's disease of grapevines. Isolation of causal bacterium. Forest Science 199:75-77.

Feeley, J.C., R.J. Gibson, G.W. Gorman, N.C. Landford, J.K. Rasheed, D.C. Mackel, and W.B. Baine. 1979. Charcoalyeast extract agar: Primary isolation medium for $L e$ gionella pneumophila. Journal of Clinical Microbiology 10:437-441.

Fletcher, R.A., and G. Hofstra. 1986. Comparative fungitoxic and plant growth regulating properties of triazole derivatives. Plant \& Cell Physiology 27:367-371.

Frakulli, F., and D.G. Voyiatzis. 1999. The growth retardants paclobutrazol and triapenthenol affect water relations and increase drought resistance in olive. Acta Horticulturae 474:427-430.

Hearon, S.S., J.L. Sherald, and S.J. Kostka. 1980. Association of xylem-limited bacteria with elm, sycamore, and oak leaf scorch. Canadian Journal of Botany 58:1986-1993.

Hopkins, D.L., and W.C. Alderz. 1988. Natural hosts of Xylella fastidiosa in Florida. Plant Disease 72:429-431.

Hopkins, D.L., H.H. Mollenhauer, and W.J. French. 1973. Occurrence of a rickettsialike bacterium in the xylem of peach with phony disease. Phytopathology 63:14221423.

Jacobs, K.A., and L.C. Berg. 2000. Inhibition of fungal pathogens of woody plants by the plant growth regulator paclobutrazol. Pest Management Science 56:407-412.

Kostka, S.J., T.A. Tattar, and J.L. Sherald. 1985. Suppression of bacterial leaf scorch in American elm through oxytetracycline microinjection. Journal of Arboriculture 11: $54-58$. 
McElrone, A.J., J.L. Sherald, and I.N. Forseth. 2001. Effects of water stress on symptomatology and growth of Parthencissus quinquefolia infected with Xylella fastidiosa. Plant Disease 85:1160-1164.

Mircetich, S.M., S.K. Lowe, W.J. Moller, and G. Nyland. 1976. Etiology of almond leaf scorch disease and transmission of the causal agent. Phytopathology 66:17-24.

Pierce, N.B. 1892. The California vine disease. U.S. Department of Agriculture, Division of Vegetable Pathology Bulletin 2:1.

Radenmacher, W., H.M. Fritschm, J.E. Graebe, H. Sauter, and J. Jung. 1987. Tetcyclacis and triazole-type plant growth retardants: Their influence on the biosynthesis of gibberellins and other metabolic processes. Pesticide Science 21:241-252.

Radenmacher, W. 2000. Growth retardants: Effects on gibberellin biosynthesis and other metabolic pathways. Annual Review of Physiology and Plant Molecular Biology 51:501-531.

Sherald, J.L., S.S. Hearon, S.J. Kostka, and D.L. Morgan. 1983. Sycamore leaf scorch: Culture and pathogenicity of fastidious xylem-limited bacteria from scorch affected trees. Plant Disease 67:849-852.

Sherald, J.L. 2001. Xylella fastidiosa, a bacterial pathogen of landscape trees. In Shade tree wilt diseases. Ash, C.L., Ed. APS Press, St. Paul, MN.

Simpson, A.J.G., F.C. Reinach, P. Arruda, et al. 2000. The Genome sequence of the pathogen Xylella fastidiosa. Nature 406:151-157.

Sugavanam, B. 1984. Diatereoisomers and enantiomers of paclobutrazol: Their preparation and biological activity. Pesticide Science 15:296-302.

Wells, J.M., B.C. Raju, H.Y. Hung, W.G. Weisburg, L. Mandelco-Paul, and D.J. Brenner. 1987. Xylella fastidiosa gen. Nov. sp. Nov.: Gram-negative, xylem limited, fastidious plant bacteria related to Xanthomonas spp. International Journal of Systematic Bacteriology 37:136-143.

Wester, H.V., and E.W. Jylkka. 1959. Elm scorch graft transmissible virus of American elm. Plant Disease Report 43:519.

Darren A. DeStefano

Department of Natural Resource Sciences and Landscape Architecture

University of Maryland

College Park, MD 20742-4452, U.S.

Arv P. Grybauskas

Department of Natural Resource Sciences and Landscape Architecture

University of Maryland

College Park, MD 20742-4452, U.S.
James L. Sherald

Chief

Center for Urban Ecology

National Park Service

4598 MacArthur Blvd., NW

Washington, DC 20007, U.S.

Bahram Momen

Department of Natural Resource Sciences and Landscape Architecture

University of Maryland

College Park, MD 20742-4452, U.S.

Qi Huang

Research Plant Pathologist

Floral and Nursery Plants Research Unit

U.S. National Arboretum

U.S. Department of Agriculture

10300 Baltimore Avenue

Beltsville, MD 20705, U.S.

Joe H. Sullivan (corresponding author)

Department of Natural Resource Sciences and Landscape

Architecture

University of Maryland

College Park, MD 20742-4452, U.S.

jsull@umd.edu

Résumé. Xylella fastidiosa est une bactérie pathogène transmise par un insecte qui s'attaque uniquement au xylème de nombreux hôtes et qui cause une flétrissure chez les arbres ornementaux. La flétrissure bactérienne est un désordre chronique caractérisé par une flétrissure en fin de saison ainsi qu'une mortalité progressive et est commune dans les zones urbaines et périurbaines du Centre Atlantique et du Sud-Est des États-Unis. La flétrissure bactérienne a été identifiée depuis les années '80 et les tentatives de traitements ont inclus l'emploi d'antibiotiques et de régulateurs de croissance de plantes. L'application de paclobutrazol, un composé avec des propriétés à la fois fongique et de contrôle de la croissance, a été observée comme étant efficace pour calmer les symptômes de la flétrissure bactérienne, mais il n'a pas encore été établi si ce produit peut avoir un effet direct sur l'organisme. Dans cette recherche, nous avons étudié l'effet du paclobutrazol sur deux souches de X. fastidiosa in vitro. Nos résultats n'ont montré aucun effet significatif du paclobutrazol sur la croissance des colonies de X. fastidiosa, et ce au taux recommandé par le manufacturier de $20 \mu \mathrm{g} / \mathrm{mL}$. Néanmoins, des diminutions significatives dans le développement de la bactérie ont été observées à un taux de $200 \mu \mathrm{g} / \mathrm{mL}$, ce qui indique que des concentrations élevées de paclobutrazol pourraient avoir un effet direct sur le développement de X. fastidiosa. Cet effet direct ainsi que les effets directs sur la croissance par le paclobutrazol laissent suggérer que ce produit pourrait s'avérer être un traitement prometteur contre la flétrissure bactérienne chez les arbres ornementaux. 
Zusammenfassung. Xylella fastidiosa ist ein anspruchsvolles, xylem-limitiertes, durch Insekten übertragenes, bakterielles Pflanzenpathogen mit einem reichen Wirtsspektrum und verursacht bakteriellen Blattbrand (BLS). BLS ist eine chronische Krankheit, gekennzeichnet durch herbstlichen Blattbrand und Zurücksterben und tritt gewöhnlich in urbanen und suburbanen Regionen in den mittatlantischen und südöstlichen Vereinigten Staaten auf. BLS ist seit den 80ger Jahren bekannt und die angewandten Behandlungen schlossen Antibiotika und Wachstumsregulierer ein. Die Applikation von Paclobutrazol (PBZ), ein diasterisches Triazol mit sowohl fungiziden, als auch wachstumsregulierenden Anteilen, wurde überwacht, um die Symptome von BLS zu mindern, aber es ist nicht gesichert, ob PBZ einen direkten Einfluss auf den Organismus hat. In dieser Studie untersuchten wir den Effekt von PBZ auf das in vitro Wachstum von $2 X$. fastidiosa Isolaten. Unsere Ergebnisse zeigten keinen signifikanten Effekt von PBZ auf das Kolonienwachstum von $X$. fastidiosa bei der vorgeschriebenen Dosierung von $20 \mu \mathrm{m} \mathrm{mL}^{-1}$. Dennoch wurden signifikante Reduktionen im bakteriellen Wachstum zu einer Rate von $200 \mu \mathrm{m} \mathrm{mL}^{-1}$, was uns zeigt, dass hohe Dosen von PBZ einen direkten Einfluss auf das Wachstum von $X$. fastidiosa haben. Dieser direkte Effekt und der wachstumsregulierende Einfluss von PBZ liefert eine viel versprechende Behandlung von BLS an Schattenbäumen.
Resumen. Xylella fastidiosa es un "fastidioso" insecto vector del patógeno bacterial de las plantas, limitado al xilema, con un amplio rango de hospederos que causa quemadura bacterial de la hoja (BLS, por sus siglas en inglés) en árboles de sombra. BLS es un desorden crónico caracterizado por quemadura foliar tardía y muerte regresiva, común en áreas urbanas y suburbanas del medio-Atlántico y el sureste de los Estados Unidos. BLS ha sido reconocido desde los ochentas y los tratamientos han incluido antibióticos y reguladores del crecimiento de las plantas. La aplicación de Paclobutrazol (PBZ), un trizol diastereomérico, con propiedades de fungistático y regulador de crecimiento, ha sido empleada para aliviar los síntomas de BLS, pero aún no ha se ha establecido si bien PBZ tiene un efecto directo sobre el organismo. En este estudio se investigó el efecto de PBZ en el crecimiento de dos aislamientos de X. fastidiosa. Los resultados no mostraron efecto significativo del PBZ en el crecimiento de la colonia de $X$. fastidiosa a la tasa recomendada por los

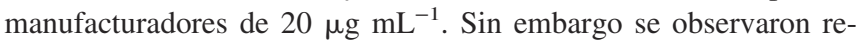
ducciones significativas del crecimiento bacterial a una tasa de 200 $\mu \mathrm{g} \mathrm{mL}^{-1}$, indicando que altos niveles de PBZ pueden tener un efecto directo en el crecimiento de $X$. fastidiosa. Este impacto directo y los efectos en la regulación del crecimiento sugieren que PBZ puede proporcionar un tratamiento promisorio para BLS en árboles de sombra. 